\title{
Transposition
}

Musique et Sciences Sociales

$8 \mid 2019$

Musique : patrimoine immatériel ?

\section{Michael Christoforidis \& Elizabeth Kertesz, Carmen and the Staging of Spain. Recasting Bizet's Opera in the Belle Époque}

New York, Oxford University Press, 2019

Lola San Martín Arbide

\section{OpenEdition}

\section{Journals}

Electronic version

URL: http://journals.openedition.org/transposition/3051

DOI: 10.4000/transposition.3051

ISSN: $2110-6134$

Publisher

CRAL - Centre de recherche sur les arts et le langage

Electronic reference

Lola San Martín Arbide, « Michael Christoforidis \& Elizabeth Kertesz, Carmen and the Staging of Spain. Recasting Bizet's Opera in the Belle Époque», Transposition [Online], 8| 2019, Online since, connection on 17 December 2020. URL : http://journals.openedition.org/transposition/3051 ; DOI : https:// doi.org/10.4000/transposition.3051

This text was automatically generated on 17 December 2020.

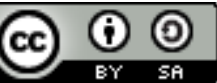

La revue Transposition est mise à disposition selon les termes de la Licence Creative Commons Attribution - Partage dans les Mêmes Conditions 4.0 International. 


\section{Michael Christoforidis \& Elizabeth Kertesz, Carmen and the Staging of Spain. Recasting Bizet's Opera in the Belle Époque}

New York, Oxford University Press, 2019

Lola San Martín Arbide

\section{REFERENCES}

Michael Christoforidis \& Elizabeth Kertesz, Carmen and the Staging of Spain. Recasting

Bizet's Opera in the Belle Epoque, New York, Oxford University Press, 2019, 328 p.

1 Since its Parisian premiere in 1875 , few operas have managed to have the same farreaching impact across the world as Bizet's Carmen. Co-authored by Michael Christoforidis and Elizabeth Kertesz (both based at the University of Melbourne), the book explores how the opera became synonymous with Spain (p. xv), and analyses the crystallization of a series of national and international images of Spanish culture through what they have termed the staging of Spain. In order to do so, they invite the reader to embark on an international journey from Mérimée's Seville to the operatic scene of cities such as Paris, London and New York, without overlooking the "Carmenesque" strands of popular entertainment inspired by the famous cigarette girl (cigarrera). The book, published in OUP's "Currents in Latin American \& Iberian Music" series, is beautifully produced and lavishly illustrated with over 70 plates, publicity photographs, stage design sketches, etc., collected from around the world.

2 Carmen and the Staging of Spain arrives at a particularly ripe time for Carmen studies. Several complementary works are soon to be published, such as Bizet's Carmen Uncovered, by Richard Langham Smith (working title, Boydell \& Brewer), Carmen Abroad, edited by Clair Rowden and Richard Langham Smith (Cambridge University Press), and 
Carmen revisitée/revisiter Carmen: les nouveaux visages d'un mythe fondateur, edited by Claire Lozier and Isabelle Marc (working title, Peter Lang). These publications will, no doubt, draw from Christoforidis and Kertesz's rich and well-documented work. Their book elaborates on the theme of the opera's ubiquity. Since its first staging, Carmen has toured the world and become one of the most performed operas ever; indeed during the 1880 s and 1890s it was always among the top five operas at the Théâtre de l'OpéraComique, when not its number one (p. 164). As demonstrated by the authors, the opera experienced a series of peaks in its popularity, coinciding with the different waves of hispanophilia that shaped the cultural milieu of Paris, New York and London. As a complement, it would have also been pertinent to consider how the circulation of certain hispanophobic ideas facilitated the celebration of a work staging a Spanish character, that of Don José, portrayed as an out of control, weak, brutal and rude man. Judging from the numerous musical criticism excerpts quoted in the book, the reader can quickly deduce - unsurprisingly, on the other hand- that audiences attended Carmen productions eager to be transported into an imaginary Spain, an imaginary exotic Other underpinned by the utopia of authenticity. Thanks to the contribution of every new "great Carmen", such as Emma Calvé, Minnie Hauk, Maria Gay, Geraldine Farrar, and others, the opera created for itself what we might call a bubble of hyperreality, sometimes leading Spanish composers themselves to conform to the stereotypes of the French-style espagnolade for the sake of international renown.

The book, therefore, cleverly contrasts the international staging of Spain with ideas, debates and problems related to national identity in Carmen's home country. This is done by exploring the staging and reception of the work in Madrid and Barcelona. The capital city is presented as the first center for the dissemination of flamenco through its growing Andalusian population, who could find the stereotypical and at times unflattering portrait of Carmen far more bothering than their Barcelona counterparts, inhabitants of a cosmopolitan, Europe-oriented city. In fact, the book presents the stark contrast between Maria Gay, the Catalan Carmen who "made two very different claims: one based on her Catalan identity, the other on Spanish nationalist rejection of foreign stereotypes" (p. 225) and the Seville-born Elena Fons, believed to be an authentic impersonation of the title role. The polarity between the castizo and cosmopolitan politics of Spanish identity is clearly scrutinized. The book relies too much, perhaps, on the Andalusian-or-nothing spectrum and thus minimizes the scope and effect of other regional pillars of national identity which can be traced back to other locations on the Spanish periphery or, alternatively, to its very core such as Castile or Madrid.

Christoforidis and Kertesz explain that theirs is a survey of how Carmen has interacted with Spain (p. xi). The book explores how the local operatic tradition and local humor gave their unique character and nuances to each new performance of the opera, the achievement of local color being precisely the gold standard to success. The authors explain how the plot was understood from its inception as a mirror of the political situation in France, with Empress Eugénie being believed to have caused the demise of Napoleon III. This review is being written in late April 2019, coinciding with the celebration of general elections in Spain, when the far-right is expected to enter Parliament for the first time since 1982. In the era of a Catalan quest for independence, current political debates have been monopolized by defining and defending Spanish national identity above everything else, and by resenting the power granted to autonomous regional governments. History displays its irony when one reads that part of the legal dispute between the Teatro Real and the Teatro de la Zarzuela over the 
rights to stage Carmen in Madrid was based on whether or not Madrid was, too, a province (p. 88). Some of the issues that caused uproar among the first Spanish critics of the opera continue to divide opinions today with regard to the "core competences" of Spanish identity. Bullfighting was incorporated into the staging of the opera at the turn of the century, for the sake of authenticity and in keeping with the progressive Andalusization and ever more aflamencada versions of the work (p. 167), although as the authors remind us it was in the southern French city of Nîmes-and not in Spainwhere the first bullring was added to the opera in 1901. Religiousness and traditional family values also played an important role in the Spanish reception of Carmen. Don José is a pious Navarrese, in contrast to the free-spirited gypsy; the role of the obedient Micaëla was created to once again counteract the revolutionary independence of Carmen; and let us not forget that on the question of the chastity of gypsy women Mérimée had deviated from one of his main sources, George Borrow's The Zincali. An Account of the Gypsies of Spain (1841). Lastly, the role of Moorish culture in modern nation building conjures up images of that almost African perfume that the expression of "l'Espagne romantique" distills. What Christoforidis and Kertesz's book does brilliantly, in this respect, is to explain how that imagined "Espagne romantique" became the real thing, the real expectation not only of many European travelers in Mérimée's context but, with time, a reality for Spanish people too, together with a standard reference against which new Spanish operas were measured, as for example Manuel de Falla's 1905 La vida breve (p. 217).

5 The book also rewrites the history of Carmen through a feminine perspective. The authors grant all the agency to the most acclaimed Carmens of the Belle Époque, and expose how they were able to use the "Carmen industry" to their benefit, that is, how they capitalized on the very industry that objectified them. Célestine Galli Marié is discussed at length, having performed the title role some 350 times between 1875 and 1883 (p. 49), a period during which Carmen came to be increasingly about the role of Carmen (p. 53). When surveying the Spanish press during this first decade of performances, one notices that much attention and enthusiasm was devoted in fact to the characters of Don José and Micaëla. This fixation with the role of Carmen caused the gender aspects of the opera to be almost exclusively focused on her. Thanks to the authors we learn for example that in 1878 a commentator in London considered Carmen's murder to be "a splendid moral for young ladies in general" that warned them "against indulging in vanity and an excessive desire for admiration" (p. 60). Recent times have seen the murder scene altered for the sake of permeating the opera not only with the current struggle for gender equality but with the global fight against domestic violence, as in Cristiano Chiarot and Leo Muscato's production premiered in Florence in 2018. The book, on the other hand, surveys a number of parodies in which this murder was already subverted. In London's 1890 Gaiety Theatre burlesque Carmen Up to Data (score by Meyer Lutz, libretto by G. R. Sims and Henry Pettitt), for example, José does not kill Carmen but instead returns to her mother; in Salvador Granés' Carmela, premiered at Barcelona's Teatro Gayarre that same year, Carmela bizarrely dies twice (p. 135). This is to say that if Carmen was then a key opera in the staging of Spanishness, it is today also a tool to stage equality. The twists used to this end might not be new in themselves, as they were present in the parodies of the Belle Époque, but the context gives new meanings to such parodic détournements updating Carmen as cornerstone of our contemporary narratives about feminism. Carmen is rather Up to Data indeed. 
6 The book discusses and includes in its framework several foreign figures who based their artistic persona on a supposed Spanishness, such as the celebrated Irish woman Lola Montez, or on a somewhat grounded claim to authenticity, such as Emma Calvé, who did in fact live in Northern Spain as a child (p. 154). But staging Carmen in Spain made those authenticity-exoticism games more complex. The descriptive terms used to portray Carmen were varied: she was the archetypal Spanish woman, the archetypal Andalusian woman, the gypsy, the savage, the working class outcast, or simply put, the cigarrera. Staging Carmen in Spain required finding an exotic within. Thus, with the passage of time the characterization of Carmen became increasingly reliant on stereotypes and commonplaces about gypsy culture. Indeed, in 1907, after Albert Carré prevented Olga Nethersole from staging the opera in Paris, the English actress got away with producing it renamed as The Spanish Gypsy (p. 187). Emma Calvé, on the other hand, ditched the castanets, more deeply embedded in the imaginaire of regional dances, and swapped Galli-Marié's kiss-curls for the magnificent femininity of adorning her hairdo with flowers, typical of gypsy women. The book also reads, therefore, as a survey of the changing canons of women's beauty and fashion. But above all, it is a story of those Carmens whose singing and acting shined above the voices of Mérimée, Bizet, Meilhac and Halévy, and made the opera about their acting or even about themselves.

7 As such, the "staging of Spain" in the Belle Époque appears as a palimpsest, which makes the diachronic approach of the book a necessary method to understand how every new production may have built on previous ones. As the authors put it, Carmen became "a recognized part of France's cultural patrimony" (p. 165), an inclusion in the national heritage dating at least back to 1904 , when it reached its 1,000 performance at the Opéra-Comique. Michael Christoforidis and Elizabeth Kertesz have created a rich source for any scholar interested in operatic transatlantic connections, the internationalization of Spanish music and gender roles in 19th and 20th century music, popular entertainment and drama. As mentioned above, this work is an important stepping stone for academics, students and music lovers interested in exploring the global dissemination of one of the most widely staged operas of all time, an issue currently being studied by the team behind the Carmen Abroad project (http:// www.carmenabroad.org, accessed on 25 April 2019), which both authors belong to. Theirs is an important contribution to a new understanding of the opera which manages to be relevant across the fields of musicology, dance, French and Spanish studies, and cultural transnational history.

\section{AUTHORS}

\section{LOLA SAN MARTÍN ARBIDE}

Lola San Martín Arbide is a Marie Skłodowska-Curie Fellow at the CRAL (EHESS-CNRS) in Paris where she is working on the book-length project Aural Paris, which investigates how the city was recreated through its sounds in literary, cinematic and musical works during the first third of the 
twentieth century. She was previously a Junior Research Fellow at the University of Oxford, as well as a Postdoctoral Fellow at the University of the Basque Country. She earned a doctorate in Musicology at the University of Salamanca with a thesis on ambient music in the $20^{\text {th }}$ century. Her publications span a variety of topics from film music, to music and literature and French opera. She has forthcoming chapters in Carmen Abroad (Richard Langham Smith and Clair Rowden, eds., CUP, 2020), Carmen revisitée (Isabelle Marc and Claire Lozier eds. Peter Lang, 2019), and Debussy in Context (Simon Trezise, ed. CUP, 2020). For a full list of publications see: http:// cral.ehess.fr/index.php?2658 